\title{
Patients' experience of using primary care services in the context of Indonesian universal health coverage reforms
}

Fitriana Murriya Ekawati ${ }^{1,3^{*}} \mathbb{0}$, Mora Claramita ${ }^{1,2}$, Krishna Hort $^{4}$, John Furler ${ }^{3}$, Sharon Licqurish ${ }^{3}$ and Jane Gunn ${ }^{3}$

\begin{abstract}
Background: The World Health Organization (WHO) recommendation on universal coverage has been implemented in Indonesia as Jaminan Kesehatan Nasional (JKN). It was designed to provide people with equitable and high-quality health care by strengthening primary care as the gate-keeper to hospitals. However, during its first year of implementation, recruitment of JKN members was slow, and the referral rates from primary to secondary care remained high. Little is known about how the public views the introduction of JKN or the factors that influence their decision to enroll in JKN.
\end{abstract}

Aim: This research aimed to explore patients' views on the implementation of JKN and factors that influence a person's decision to enroll in the JKN scheme.

Methods: This study was informed by interpretative phenomenological analysis (IPA) methodology to understand patients'views. The interview participants were purposively recruited using maximum variation criteria. The data were gathered using in-depth interviews and was conducted in Yogyakarta from October to December 2014. The interviews were transcribed, translated and analyzed using IPA analysis.

Result: Twenty three participants were interviewed from eight primary care clinics. Three superordinate themes: access, trust, and separation anxiety were identified which impacted on the uptake of JKN. Participants acknowledged that whilst primary care clinics were conveniently located, access was often complicated by long waiting times and short opening hours. Participants also expressed lower levels of trust with primary care doctors compared to hospital and specialist care. They also reported a sense of anxiety that the current JKN regulation might limit their ability to access the hospital service guaranteed in the past.

Discussion: This study identified patients' views that could challenge the implementation of the gate-keeper role of primary care in Indonesia. While the patients valued the availability of medical care close to home, their lack of trust in primary care doctors and fear that they might lost the hospital care in the future appears to have impacted on the uptake of JKN. Unless targeted efforts are made to address these views through sustained public education and further capacity building in primary care, it is unlikely that the full potential of the JKN scheme in primary care will be realized.

Keywords: General practice, Primary health care, Indonesia, Access, Patients' experience, Phenomenology

\section{Background}

The WHO [1] has proposed that all member countries implement universal health coverage to help people

\footnotetext{
*Correspondence: fitriana_murriya@yahoo.co.id; fekawati@student. unimelb.edu.au

1 Department of Family and Community Medicine, Faculty of Medicine, Universitas Gadjah Mada, Yogyakarta, Indonesia

Full list of author information is available at the end of the article
}

access high-quality health services without financial barriers. This $\mathrm{WHO}$ recommendation of universal health coverage was in-line with the Alma Ata declaration which aimed to provide people with accessible highquality services in primary care [2, 3]. Responding to those global recommendations, Indonesia has established a universal insurance scheme, which is known as Jaminan Kesehatan Nasional (JKN) since January 2014. The 
JKN was the merger of four pre-existing public insurance schemes (Askes insurance for civil servants, Jamkesmas insurance for poor citizens, Jamsostek as insurance for private sector workers and Asabri as Insurance for the armed forces). The JKN was designed under the law of National Social Security to meet the people's basic needs and contribute towards the realization of a prosperous and equitable Indonesia $[4,5]$. With this insurance, it was expected that people would not face financial barriers to access health care and therefore increase their use of health services.

The role of primary care as a gatekeeper to secondary and tertiary care has been strengthened in the JKN implementation. It is expected that primary care doctors can fulfill the people's basic health needs and ought to be able to manage the majority of the patients' problems [6]. In the JKN implementation, this sector is supported under a capitation payment system [7]. It is a payment concept within which the private family doctors and Puskesmas (Indonesian Public Primary Care Clinic) as primary care providers are paid a set payment per number of registered patients, whether the patients come to seek any medical help or not. This payment scheme is intended to enable primary care services to focus on health promotion and illness prevention in addition to curative measures [7].

The JKN also introduced several new regulations of the health system compared to the previous insurance schemes. Under the Askes and Jamkesmas schemes in the past, patients were free to access any primary care service. They also could easily obtain a referral letter from their general practitioner (GP) to access secondary care in hospitals [8]. However, under the JKN scheme, patients have to formally register themselves at JKN offices or their appointed family doctor practice or Puskesmas. The guidelines of conditions that could be appropriately managed by the GPs-based on their competency standard [9] -had also been published [10]. The referrals could only be made on appropriate clinical judgements. Therefore, the patients have to comply with these procedures set by the JKN, under which, JKN will not cover the cost of any hospital treatment if the referral is made outside the guidelines $[11,12]$. On the other hand, the Indonesian government also supported the utilization of primary care under the JKN by disseminating information on JKN procedures to the public and preparing practice guidelines for primary care providers. The information was spread by a massive media campaign including advertisements on TV and radio; while procedures were established to make registration with JKN easier for patients.

However, an additional policy that could contribute significantly to the success of JKN primary care objectives has yet to be fully established. This relates to the requirement for GPs to undertake compulsory formal training to improve their primary care practice. In 2015, 168,823 doctors were registered with the Indonesian Medical Council: 29,561 of them were specialist doctors, 29,665 were dentists, and 109,597 were recorded as GPs [13]. In Indonesia, doctors only need to undertake a four year undergraduate degree plus a two years postgraduate Medical Doctor (MD) degree, national examination, and one year internship in hospitals and Puskesmas to get the licence to practice as a GP in primary care [14]. During the undergraduate degree, the students learn the theory required to practise medicine. During the MD, they complete two years of clinical practice in various hospital departments; such as internal medicine, surgery, dermatology, and obstetrics. While the specialists have to complete an additional three to five years training at the University hospitals, currently, no compulsory training for GPs is available to upgrade their skills in primary care practice. Therefore, this level of training for Indonesian GPs differs from the requirements in other similar countries that are implementing universal insurance coverage. In Thailand for example, GPs have been required to undertake a formal postgraduate training in family medicine. This education scheme has been implemented since 20 years before the implementation of Thailand's universal coverage in $2001[15,16]$.

Some important issues arose during JKN's first years of implementation, notably slow recruitment of new members, which was identified at the first JKN mid-year evaluation. Compared to the total membership of the four previous insurances schemes in 2012 (155 million members), the JKN membership had only reached 125 million members in mid-2014 [10, 17]. The target of doctors to handle almost all of the primary care cases and only refer less than $10 \%$ of the cases was also not being met. Nationally, the overall JKN primary-to-secondary referral rate was $17 \%$, but the referral rate in several provinces such as in Yogyakarta, East Java and Jakarta was much higher, up to $55 \%$ of cases $[18,19]$. With this high referral rate, it is likely that many of the referrals were inappropriate, such as essential hypertension, dyspepsia, and general physical examination [11], conditions which should be managed at primary care level according to the Indonesian physicians' competency standards for primary care doctors $[9$, 17].

Unfortunately, there has been little evidence available about the factors that underlie these emerging issues during the initial implementation of JKN in primary care settings. In particular, there is little known of patients' views and experiences during JKN implementation, which may be important factors influencing their decision about whether to opt into the JKN. Information on the views of patients is important because patients are the actual 
users of health care, and their views and experiences represent the actual condition in practice settings [20,21].

Current available evidence only shows that there are different satisfaction rates with the JKN program across Indonesian provinces. Gaghana, Siagian [22] found that only $51.9 \%$ out of 106 patients were satisfied with JKN implementation in Sulawesi. Putri [23] also found the implementation of JKN was not effective in primary care clinics in Padang city, West Sumatra. Putri found that the JKN improved service delivery for low socioeconomic status patients, but the patients expressed dissatisfaction with the staff responsiveness, credibility, medical documentation, and medical access. However, neither of these studies explored in depth the factors which contributed towards the patients' views nor their dissatisfaction. Therefore, we set out to explore in depth the patients' perspectives of primary care in this study, and the factors which contribute towards the slow recruitment and high referral rates to secondary care $[10,17]$.

\section{Methods}

This research was informed by the interpretative phenomenological analysis (IPA) approach to allow a deep and comprehensive understanding of the participants' views and experiences [24]. Consistent with this approach, data collection was conducted using semistructured interviews to allow greater opportunity for patients to express their views.

The study was conducted in Yogyakarta province, central Indonesia, from October to December 2014. Yogyakarta is characterized by a range of socio-economic status of its population, relatively easy access to health services and a high rate of referral to secondary care. A maximum variation sampling strategy was applied to ensure a range of perspectives. The clinic recruitment process was done purposively in both private and public primary care clinics in the Yogyakarta region: at the districts of Kulonprogo, Sleman, Yogyakarta city, Bantul, and Gunung Kidul.

The recruitment process is described as follows: first, the practice manager/clinic owners were telephoned and were provided with Bahasa Indonesia plain language statement. When the practice manager/clinic owner had signed the consent form, first author (FM) then came to the clinics to recruit patients for an interview. The patients were selected purposively from the patients' registry during the interview day (at maximum three participants at each clinic). The inclusion criteria included: Indonesian citizen, JKN insurance member, and Yogyakarta resident. Then, the patients were selected based on the following purposive sampling criteria: age, income level, the level of education, residential address, marital status, and specific characteristics; such as whether they were a parent or a caregiver. The only exclusion criterion was if patients were unwilling to participate in the research.

The first author (FM) completed all of the interviews. Written informed consent was obtained from all study participants prior to the interview. All of the interviews were done in a private room in the clinics, except two interviews which were done in FM's office. None of the participants expressed any objection with the interview place. FM had also anticipated that Yogyakarta people may be reluctant to speak openly about their views [25] or may be hesitant because FM is a GP from Yogyakarta. FM therefore explained to the participants that their participation was voluntary, their answers were confidential, and that their participation would not affect their relationship with FM or with their care providers in the future.

During the interviews, FM began with an introduction. After that, she asked open-ended questions, such: 'please tell me your experience in seeking health care' or 'where do you usually go to seek health care.' Then, these questions were followed up with more focused interview questions related to the participant's experience with the primary care service and the JKN implementation. The participant responses were probed and clarified using prompting sentences, summarizing sentences and or some positive statements such as uhum..., or 'yes ....' and silent pauses to allow time for participants to think about their responses and respond. All but one interview was taperecorded. Written notes of responses were taken for the patient who was unwilling to be tape-recorded. All the participants were given a small souvenir bag as a token of their participation.

The interviews were transcribed and then, translated into English. Five translated texts were back translated for translation validation. The data were analyzed using IPA analysis. IPA is an analytical method to explore in depth the participants' views, combined with the researcher's interpretation of the participant's meaning of a phenomena. The steps of IPA analysis were systematically applied according to the recommendations of by Smith and Osborn [26]. FM and JG read all the transcribed texts independently until they were also familiar with the patients' views. They both then coded any notable quotes. The quotes were grouped into themes and super-ordinate themes. The emerging themes were discussed and crosschecked amongst other researchers with primary care backgrounds.

\section{Results}

The proposed maximum variation sample design for interview participants was fulfilled. The criteria for the sample are listed in Table 1. All criteria were met with at 
Table 1 The participants' characteristic

\begin{tabular}{|c|c|}
\hline Sample criteria & Total number $(\mathrm{N}=23)$ \\
\hline \multicolumn{2}{|l|}{ Types of clinic } \\
\hline Public clinic & 5 \\
\hline Private clinic & 3 \\
\hline \multicolumn{2}{|l|}{ Gender } \\
\hline Male & 7 \\
\hline Female & 16 \\
\hline \multicolumn{2}{|l|}{ Age group } \\
\hline $18-25$ & 4 \\
\hline $26-45$ & 8 \\
\hline $46-65$ & 7 \\
\hline $66-85$ & 4 \\
\hline \multicolumn{2}{|l|}{ Residential address } \\
\hline Urban area & 11 \\
\hline Rural area & 12 \\
\hline \multicolumn{2}{|l|}{ Education level } \\
\hline High education & 13 \\
\hline Low education & 10 \\
\hline \multicolumn{2}{|l|}{ Income level } \\
\hline High income & 6 \\
\hline Middle income & 12 \\
\hline Low income & 5 \\
\hline \multicolumn{2}{|l|}{ Employment sector } \\
\hline Private sector & 7 \\
\hline Public sector & 16 \\
\hline \multicolumn{2}{|l|}{ Frequency use of primary care } \\
\hline Never & 4 \\
\hline $1-5$ visits/year & 8 \\
\hline$>5$ visits/year & 11 \\
\hline \multicolumn{2}{|l|}{ Marital status } \\
\hline Married & 18 \\
\hline Single & 5 \\
\hline \multicolumn{2}{|l|}{ Diagnoses } \\
\hline Acute illness & 5 \\
\hline Chronic illness & 9 \\
\hline Healthy & 9 \\
\hline \multicolumn{2}{|l|}{ Specific attributes } \\
\hline Only caregiver & - \\
\hline Parent & 13 \\
\hline Both of caregiver and parent & 5 \\
\hline None & 5 \\
\hline
\end{tabular}

minimum two participants in each category. 23 participants were recruited, the majority of whom were women $(\mathrm{n}=17)$, had a high level of education (at minimum a bachelor degree) $(\mathrm{n}=13)$, were aged between 26 and 65 years old, and of middle-income status/income per month: 1-5 million IDR $(\mathrm{n}=12)$. The majority of participants were members of the previous insurance schemes, with 13 past members of Askes (civil servants scheme), and 6 were past members of Jamkesmas (free insurance for low-income/poor). Almost all the participants were willing to fully participate right up until completion of the interview. One participant suddenly decided to stop in the middle of the interview process but did not wish to withdraw completely from the study because of her worries that the interview would affect her treatment in the clinics.

Three superordinate themes of Access, Trust, and Separation anxiety were identified from the analysis. Participants acknowledged the convenience of access to primary care but were dissatisfied with the waiting time and physical structure of the clinics. The superordinate theme of Trust referred to participants who were dissatisfied with the doctors' general communication. They also expressed doubt that the primary care doctors could treat more severe diseases and preferred to receive a referral letter to secondary care. Within the third superordinate theme, participants expressed their anxiety about whether they would be able to continue to use specialist care services at the hospital in the way they were previously used to.

\section{Access}

Many participants referred to the proximity between the service and their home and the convenience of access to primary care service and chose them as their usual means of health care. This answer also came from many participants when being asked about their reason for attending primary care. For instance, Participant 21 in this study said "Yes, every month I go to Puskesmas. Because it is near, so that I can get the easily accessible service" (Participant 21, 1.24-25).

However, later on, during the interviews, many participants commented that the long waiting time and facilities in the clinics were less convenient and limited their enjoyment of the service. In some cases, the participants then preferred to leave the clinics or chose to attend a private hospital rather than continue queuing. For example, Participant 9 said: "If in Puskesmas, I need to queue for a long time. I have to queue before here and there. But, I need to go to fieldwork (working), so I decide to leave the Puskesmas and go to private hospital" (Participant 9, $l$. 38-39).

In addition, participants also noticed deficiencies in the physical facilities at the clinic which influenced the ease with which they could see the doctor. They considered that the clinic building could not accommodate them well and caused them to wait longer to see the doctors, as stated by Participant 11:

"If all patients need and go to Puskesmas, I believe that it is not only unbalanced, but it is impossible. This Puskesmas does not have enough room for that, 
and we will wait longer and longer. The parking lot, Puskesmas also can't provide an enough time for us (Participant 11, l.57-65).

Some participants also commented on the facility inequalities across Indonesia's geography. Participants 1 and 16 thought that service on the island of Java (where Yogyakarta is located) was actually better than the service in other islands. They felt that although JKN had already helped people with affordable medical cost, it still did not resolve the inequalities and hindered access to high-quality medical care for people residing outside Java, due to the imbalanced and non-standardized health facilities in different geographic areas.

"Who gets the benefits, I think, once again are Javanese, Can you imagine? In East Nusa-Tenggara, on the top of the mountain, a member of JKN, she needs a bypass of her heart, can she? Because they are people who cannot be served, they should have the same rights; they should get the same, but in fact, they receive different service. Big fake as long as the government does not think about the infrastructures, doctors' distribution, hospitals and the nurses." (Participant 1, l.182-186).

\section{Trust}

Participants were initially unsure when asked about the quality of the primary care doctors' service. They usually answered with comments such as the doctors are kind' or 'I feel comfortable with the doctors' as their first reply. However, when they were encouraged to give more description about what they expected from their GPs, they expected that GPs should have excellent communication skills and be able to explain more about the patients' condition. For instance, Participants 11 and 12 were dissatisfied with the doctors' service because the doctors did not explain more about their illnesses. They thought that the doctors only gave similar pills for all patients without adequate information. They expected the GPs to perform a comprehensive individual examination and provide a complete explanation of their condition so that they understood the purposes of the medication and trusted the doctors' treatment.

"So usually in Puskesmas, you see that after the doctor asks us, then he will give us some medicine? Then we do not know what is our disease is. So I think the doctor only treat our symptoms. So my hope is that we are asked comprehensively. So that we know our problem, not only fever, then the doctor gives us the fever drug. However, then we develop an infection and not yet informed. Every- one is given antibiotic". (Participant 12, l. 68-72).

Another prominent aspect of patients' trust in their GPs is that many participants also doubted if the GPs could manage more severe problems. They considered that the GPs' current education could only equip them with skills to superficially understand the patients' conditions. Many of them expressed the opinion that their GPs were unable to solve more serious illnesses, as was explained by Participant 8 :

"The GP is a general doctor, their education is limited. I think for the specific diagnosis, the internist's (diagnosis) is better, specific in the treatment as well. The GP doctors, I believe they need to learn again" (Participant 8, l. 61-62).

Furthermore, some participants insisted that the GPs' role should be to provide referrals to hospital. There was a perception among patients that if a person was suffering from any illness, they needed to see a specialist and the primary care doctors should give them referrals to hospital, as expressed by Participant 16:

"I usually get referrals from here. A long time ago, I must be inpatient in S hospital; I got the referral from here. I also once had a referral from here for a urinary infection. When my child was sick, I came here. Sometimes I think the primary care is not needed, but the pediatrician. My child's eyes were red and got swelling several times, which we are referred to J hospital. My wife also comes here, my mother in law also gets the referral here" (Participant 16, l. 41-48)".

Meanwhile, participants also considered that specialist doctors were also superior because of their more comprehensive facilities. Participant 6 stated that she was pessimistic with the clinic service because it had less medical facilities. She said that this made the GPs use less effective medication and limited the help they could provide for the patients' problems, whereas, specialist care was always trusted as it was always complemented with more advanced medication. Interestingly, Participant 6 also believed that diseases of certain body parts belonged to certain specialist expertise. She thought that as nowadays many patients suffered from internal diseases. She then expected the clinic to have an internist doctor.

"I think it will be good if you can provide an ophthalmologist because you know, it is a pity for many people here with cataract, an eye-wart, an eye spot, sometimes ago, they were here and could not be treated. For eye diseases in Puskesmas, we were only given an eye drop. I do not think Puskesmas can give anything else for cataract patients, for now, I do not 
know for the future. But with the eye drops, when I used it, I do not feel any improvement, Somewhat my eyes are getting bright but often darker, it is not working. Moreover, please, you may add this clinic with an internist. You know there are lots of patients with internal diseases" (Participant 6, l. 78-90).

\section{Separation anxiety}

Thus, with the JKN transition, half of the participants in this study experienced JKN implementation in primary care as a challenging period because they no longer had the same access to the specialist services, which they regarded as superior to primary care-that they had been guaranteed in the past. Many participants, who had been managed by specialists for a long time, now had to visit the GPs for their routine care. They also claimed that JKN restricted the prescription of medicines and their referral access to the hospital. As they already had limited trust in the GP's ability (-as described at 'Trust' theme), patients worried if the GP care was less ideal than specialist care as expressed by Participant 2:

\section{"Well, this is just my opinion. You know that I should be referred to an internist because I have diabetes. Previously, I was happy in G clinic (specialist clinic), I could see the internist directly. You know if here, I have to use the referral system, which is once in every three months in the hospital. I need to see the GPs for months. I think that is too long. However, anyhow, I kept ask my doctor to refer me to specialist and now the doctors refer me" (Patient 2, l. 49-52).}

Participants were more emotionally discouraged because JKN had also limited some hospital services which had previously been covered by Askes insurance. Even though they had already had referrals to the hospital, it did not mean that JKN would cover the all the hospital medical expenses. Participant 21 mentioned that some services were not fully covered by JKN anymore, compared to Askes insurance in the past. She also expressed her feeling that somehow she was happier with the old Askes insurance.

"I think with Askes if we come to health facilities whatever whenever, were not limited, but now, we have our limit. However, last month when my son had surgery, he should pay himself. It is stated at JKN paper that it is only covered for 15 million so that he had to pay the gaps. You know, it would not happen in Askes. That was different between them. For JKN, if the patient is not very ill and she is referred hospital, it will not be covered. We have to pay, come to the emergency room and pay. However, Askes was not. For me, they are different. I am hap- pier with Askes because we do not have our limit".

(Participant 21, l. 72-79).

Moreover, half of the participants also complained that clear information regarding JKN procedures was limitedly available. They were unfamiliar with current JKN transition systems in primary care. Even though there was increasing efforts to promote the changes that had been made, access to information in the primary care setting was lacking. Moreover, the clinic's staff failed to assist patients in obtaining adequate information. For example, Participant 1 told of his experience in using a referral to access hospital care without knowing that the regulations were changing. He was dissatisfied because his referral to the hospital was no longer allowed and this was not informed by the clinic's staff. He was concerned that the same situation could be experienced by another patient who needed urgent medical help.

"I came at noon, Oh My God, the hospital officer showed me that referral was not working. She told me that the regulation was changing, I should go to the secondary hospital first. I mean, how about the other patients, if he was certain with the referral, but it did not work? How about if there is a severe patient, more serious than me, how is that?" (Participant 1, l. 107-112).

\section{Discussion}

Our findings suggest that during the commencement of the JKN universal health coverage scheme, Indonesian primary care faces some challenges in achieving the aims of the program. The limitations in facilities and operation have constrained the fulfillment of the patients' perceived general health needs and reduced the public's expectations regarding the JKN implementation in primary care.

The findings regarding the clinics access are consistent with existing research. Putri [23] found that patients reported inadequate access to primary care clinics during JKN insurance. Regarding this finding, one strategy to improve the facilities and access standard of care by providing an equal access of health care distribution [27] and establishing an accreditation program so that the care quality for the patients is warranted [28].

Even though still a distance from the ideal views of those suggestion, however, the health care distribution is currently the Indonesian priority. The government has currently established an accreditation standards required for primary care practice. The Puskesmas and private clinics that wish to contract with the JKN are expected to prepare and maintain their facilities to the required, specified standards of care, such as the fixed opening hours and patient care standard operating procedures. 
However, this program is currently ongoing and focusing on the Puskesmas [29], not yet involving the private primary care practices accreditation. The health care providers availability is also continuing to improve through several programs, such as contract doctor, Nusantara Sehat [30] and local public agency program which enable Puskesmas to arrange and manage its own facilities [31].

Another important finding in this research is that patient perceptions of the quality of the GPs practice also significantly influenced their trust in primary care settings. While the JKN seeks to establish GPs as gatekeepers in primary care, patients expressed different views on the GP practice. Some key elements of primary care, such as adequate communication, were less prominent in comparison to the patients' comments that the GPs should refer them to secondary care [32]. This finding about the GPs care complemented another study findings on GPs experience that the they were currently focused on restricted policies in primary care practices and limitedly covered the trust issue between them and the patients [33].

Our result showed that the patients' limited trust in GPs was very likely correlated with their views on the current doctors' education that only enabled them to manage mild illnesses as what had been said by Participant 8 . This finding is new and limitedly discussed in Indonesian literature. Meanwhile, the patients' trust to their GPs was an important factor that contributed towards the high referrals from primary care [17]. Likewise, research in Central Asia [33], China [34] and Thailand [35-38] showed that the GPs' roles were diminished because patients put less trust in them than specialists because of their shorter training. One strategy that could help build the patients' trust in GPs in these countries is to include family medicine education as a compulsory element of GPs' postgraduate training. The training could focus on preparing GPs to perform person-centred communication and to manage common cases in primary care $[33,39]$. In Thailand, this training was successful in equipping the GPs to improve their gate-keeper role during the implementation of Thailand's universal coverage scheme. The rate of inappropriate referral to secondary care could be minimized, patients could benefit from more appropriate care and the health financing system could be more efficient [16, 38].

Fortunately, the Indonesian government has also currently proposed such family medicine training for the GPs, but the implementation is still pending. Primary care training for GPs is already included in the Indonesian Medical Education Act number 20 the year 2013 [40]. The Indonesian National Board of Primary Care Physicians' which brings together representatives of 17 major faculties of medicines has been preparing the formal postgraduate training for the GPs. However, there has been an extensive debates among GPs' and specialist colleagues regarding the training time, resources, and care collaboration. Concerns have been raised that the postgraduate training would lengthen the GPs' education to practice in primary care and that the training would be ineffective without ensuring adequate facilities were available in the primary care settings [41]. Therefore, recognition of prior learning (RPL) has been offered as an alternative, so that the current GPs will still be able to practice while they have the training. Unfortunately, until now, the debate is continuing and is prolonging the delay to establish a formal GP training. This delay could hinder improvement in the quality of practice and prolong the uncertainty among patients on the quality of primary care services [42].

Besides by upgrading the GPs capability, there is also a need to establish a clinical pathway guidelines [27]. This guideline would be very important as the GPs reference to provide a comprehensive care for their patients and manage the patients' referrals. Even though the Indonesian Ministry of Health has published the Primary Care Guideline for GPs in Primary Care [43], its improvement is needed, particularly to provide the a care collaboration for re-referral mechanism between GPs and specialist in secondary care.

In addition to the factors related to the primary care access and the GPs care discussed above, the patients' experience during JKN implementation in this study was also influenced by their experience with previous insurance schemes. Patients were unaware of the JKN changes and frequently compared their JKN experience with Askes (former scheme for civil servants) insurance, so that when the JKN strictly regulated some aspects of care, patients experienced dissatisfaction. Unfortunately, the available information failed to assist the patients in understanding the aims of JKN transition and the new role of primary care service. Therefore, a more extensive public information campaign in television, radio, or at any community meetings is essential so that people can understand what is $J \mathrm{KN}$, what is covered, what is not covered, and what are the GPs' roles in the JKN scheme. While the literature showed that GPs also felt overwhelmed with the JKN working load [44], an insurance specialist may also help to inform the patients about any JKN regulation changes at the clinics settings.

\section{Conclusion}

In conclusion, this study filled in the gaps of literature of patients' views about the implementation of JKN in primary care. This study concludes that the objectives of universal coverage in primary care have not yet been fully realised in Yogyakarta. To strengthen the JKN 
implementation, a change in public attitudes about universal coverage and the role of primary care practice is required. The public's preference for hospital care, and trust in primary care, could be shifted by a better understanding of the benefits of primary care services. Those changes, obviously need the collaboration of all the parties involved in the JKN transition, particularly to support the primary care sectors to provide a high-quality service for patients, including the role of media to support the dissemination of information. Unless these issues of primary care are addressed, universal care will be difficult to achieve, and the public medical expense will remain high with inappropriate expense paid for unnecessary procedures in secondary and tertiary care $[6,16,45]$.

This research has also provides a foundation for further deep investigation into doctors' views and experience practicing with the Indonesian JKN as well as the Indonesian people's opinions about postgraduate training in primary care/family medicine.

\section{Strengths and limitations}

This study was a qualitative study with a relatively small sample of participants from Yogyakarta, and the findings should be interpreted and applied within the appropriate context, and might not represent the full range of donesian geographic diversity. The recruitment process was able to achieve data collection from a range of sources, and we are confident that our strategy to analyze the data using interpretative phenomenology has strengthened the findings and conclusions.

\footnotetext{
Abbreviations

Askes: Asuransi Kesehatan (Insurance for Indonesian civil servants); GP: General Practitioner; Jamkesmas: Jaminan Kesehatan Masyarakat (Insurance for the poor citizens); Jamsostek: Jaminan Sosial Tenaga Kerja (Insurance for workers); JKN: Jaminan Kesehatan Nasional (Indonesin universal health coverage); IPA: Interpretative Phenomenological Analysis; Puskesmas: Pusat Kesehatan Masyarakat (Indonesian public primary care clinics).
}

\section{Authors' contributions}

All of the authors were involved in the study. FM is an Indonesian. She is working as a GP and academic at Universitas Gadjah Mada. FM and JG were involved in the study design, data collection, interpretation of the data and analysis. SL supervised FM on her qualitative interviewing training. MC was solely responsible for the FM fieldwork. MC, KH, SL, JF and JG provided essential comments during the analysis, the interpretation of the data and revised the publication drafts. All authors read and approved the final manuscript.

\section{Author details \\ ${ }^{1}$ Department of Family and Community Medicine, Faculty of Medicine, Universitas Gadjah Mada, Yogyakarta, Indonesia. ${ }^{2}$ Department of Medical Edu- cation, Faculty of Medicine, Universitas Gadjah Mada, Yogyakarta, Indonesia. \\ ${ }^{3}$ Department of General Practice and Primary Health Care, University of Mel- bourne, Melbourne, Australia. ${ }^{4}$ Nossal Institute of Global Health, University of Melbourne, Melbourne, Australia.}

\section{Acknowledgements}

The authors would like to acknowledge the contribution of the Professor Adi Heru as the Head of Department of Family and Community Medicine, Universitas Gadjah Mada for the legitimation letter and Riadiani for her administrative assistance during our fieldwork in Yogyakarta.

\section{Competing interests}

All authors declare that they have no competing interests.

\section{Availability of data and supporting materials}

Please contact corresponding author for any data and supporting materials requests.

\section{Consent for publication}

All the participants had given their consent for their participation and academic publications using their pseudonyms.

\section{Declarations}

This study was approved by the Human Research Ethics Committee, The University of Melbourne, Number 1442357. Research permits were obtained from Regional Development Offices (BAPPEDA) Number 070/REG/3548/S2/2014 in Yogyakarta province as well as local health offices in all Yogyakarta regencies.

Funding

This research was funded under the scheme of Australia Awards Scholarship from Department of Foreign Affairs and Trade, Australia.

\section{Appendix}

See Table 2. 
Table 2 Detailed background of participants

\begin{tabular}{|c|c|c|c|c|c|c|c|c|}
\hline $\begin{array}{l}\text { Participants } \\
\text { order }\end{array}$ & Clinics origin & $\begin{array}{l}\text { Clinic charac- } \\
\text { teristic }\end{array}$ & Gender & Age range & Education level & Income level & $\begin{array}{l}\text { Residential } \\
\text { address }\end{array}$ & $\begin{array}{l}\text { Previous } \\
\text { insurance } \\
\text { coverage }\end{array}$ \\
\hline 1 & Clinic 1 & Private & Male & $26-45$ & High & Middle & Urban & None \\
\hline 2 & Clinic 2 & Public & Male & $46-65$ & Low & Middle & Rural & Askes \\
\hline 3 & Clinic 1 & Private & Male & $18-25$ & High & Middle & Urban & Askes \\
\hline 4 & Clinic 3 & Private & Female & $18-25$ & High & Middle & Rural & None \\
\hline 5 & Clinic 4 & Public & Male & $46-65$ & Low & Middle & Rural & None \\
\hline 6 & Clinic 4 & Public & Female & $46-65$ & Low & Low & Rural & Jamkesmas \\
\hline 7 & Clinic 4 & Public & Female & $46-65$ & Low & Low & Rural & Jamkesmas \\
\hline 8 & Clinic 3 & Private & Male & $46-65$ & High & High & Rural & Askes \\
\hline 9 & Clinic 3 & Private & Female & $26-45$ & High & Middle & Rural & Askes \\
\hline 10 & Clinic 5 & Public & Female & $18-25$ & High & Middle & Urban & Askes \\
\hline 11 & Clinic 5 & Public & Male & $26-45$ & High & High & Urban & None \\
\hline 12 & Clinic 5 & Public & Female & $18-25$ & High & Middle & Urban & Askes \\
\hline 13 & Clinic 6 & Public & Female & $26-45$ & Low & Low & Rural & Jamkesmas \\
\hline 14 & Clinic 6 & Public & Female & $26-45$ & High & Middle & Rural & Askes \\
\hline 15 & Clinic 2 & Public & Female & $26-45$ & High & High & Urban & Askes \\
\hline 16 & Clinic 2 & Public & Male & $26-45$ & High & High & Urban & Askes \\
\hline 17 & Clinic 1 & Private & Female & $66-85$ & High & High & Urban & Askes \\
\hline 18 & Clinic 7 & Public & Female & $66-86$ & Low & Low & Rural & Jamkesmas \\
\hline 19 & Clinic 7 & Public & Female & $46-65$ & Low & Low & Rural & Jamkesmas \\
\hline 20 & Clinic 7 & Public & Female & $26-45$ & Low & Middle & Rural & Jamkesmas \\
\hline 21 & Clinic 8 & Private & Female & $66-86$ & Low & Middle & Urban & Askes \\
\hline 22 & Clinic 8 & Private & Female & $66-87$ & Low & Middle & Urban & Askes \\
\hline 23 & Clinic 8 & Private & Female & $46-65$ & High & High & Urban & Askes \\
\hline
\end{tabular}

High education: minimum undergraduate degree, low education: maximum senior high school; high income: average income per month above 5.000.000 IDR, middle income: Average income per month 1.000.000 IDR-5.000.000 IDR, Low income: average income per month less than 1.000 .000 IDR; Rural area: living in a rural area (Respondents live more than $20 \mathrm{~km}$ from the CBD), Urban area: living in a urban area (Respondents live within a $20 \mathrm{~km}$ radius from CBD)

Received: 13 December 2016 Accepted: 16 February 2017

Published online: 21 March 2017

\section{References}

1. Assembly World Health. Social health insurance: sustainable health financing, universal coverage and social health insurance: report by the Secretariat. 58th World Health Assembly. Geneva: World Health Assembly 2005 May 16-25 2005. Report No.

2. WHO/UNICEF. Primary Health Care: report of the International Conference on Primary Health Care, Alma Ata, USSR, 5-12 September 1978. Geneva: World Health Organization; 1978.

3. WHO. Primary Health Care: now more than ever. Geneva: 2008.

4. Indonesia the Parliament of Republic, Indonesia The President of Republic. The Indonesian Law Number 40 about National Social Security System. Jakarta 2004.

5. Assembly Indonesian Parliament, Undang Undang Dasar Republik Indonesia 1945/The Indonesian Law of Constition 1945. Sect. Preambulethe Introduction; 1945.

6. Starfield B, Shi L, Macinko J. Contribution of primary care to health systems and health. Milbank Q. 2005;3:457.

7. Indonesia the President of, the President's Regulation No 12 Year 2013 about Indonesian Health Coverage, 1; 2013. http://www.jkn.kemkes go.id/attachment/unduhan/Perpres\%20No.\%2012\%20Th\%202013\%20 ttg\%20Jaminan\%20Kesehatan.pdf.

8. Sista Kanina. The correlation study of disease severity perception and obedience to follow referral procedure in internist clinic Sardjito Hospital
Yogyakarta (Hubungan Antara Persepsi Keparahan Penyakit Dengan Kepatuhan Mengikuti Sistem Rujukan Berjenjang Di Poliklinik Penyakit Dalam Rsup Dr. Sardjito Yogyakarta). Yogyakarta: Sista Kanina; 2010.

9. Council Indonesian Medical, Indonesian Doctors' Competency Standard; 2006.

10. Idris F. Evaluasi Pelaksanaan JKN. Angka rujukan bpjs 2014 di yogyakarta; 2014.

11. Kesehatan BPJS. Sistem Rujukan Berjenjang Jaminan Kesehatan Nasional, 1. Sect. Primary care. 2014. http://www.bpjs-kesehatan.go.id/bpjs/dmdoc uments/588c8bcc7941c2b6d0187435dbcaba61.pdf.

12. Kesehatan BPJS. Panduan praktis Pelayanan Kesehatan. Jakarta: BPJS Kesehatan; 2014. http://bpjs-Kesehatan.go.id/bpjs/index.php/arsip/categories/OQ/manlak-jkn-bpjs-kesehatan. Accessed 5 May 2015.

13. Council Indonesian Medical. Laporan Tahunan Konsil Kedokteran Indonesia/Indonesian Medical Council Report 2015. Indonesian Medical Council 2015.

14. Claramita M, Sutomo AH, Graber MA, Scherpbier AJ. Are patient-centered care values as reflected in teaching scenarios really being taught when implemented by teaching faculty? A discourse analysis on an Indonesian medical school's curriculum. Asia Pacific Fam Med. 2011;10(1):4.

15. Prueksaritanond S, Tuchinda P. General practice residency training program in Thailand: past, present, and future. J Med Assoc Thail Chotmaihet Thangphaet. 2001;84(8):1153-7.

16. Pongsupap Y. Family medicine and community orientation as a new approach to quality primary and person-centered care in Thailand. Int J Pers Cent Med. 2014;3(3):243-7.

17. Health Indonesian directorate general of health service. Sistem Rujukan Belum Optimal: Jakarta; 2014. 
18. Ministry of Health Indonesia. Indonesian Health Profile (2014) in Bahasa Indonesia. Jakarta: Ministry of Health; 2015. http://www.depkes.go.id/ resources/download/pusdatin/profil-kesehatan-indonesia/Indonesia\%20 Health\%20Profile\%202014.pdf.

19. DJSN. Laporan perkembangan 1 tahun BPJS kesehatan, media release. 2014. djsn.go.id. Accessed 14 May 2015.

20. Arnstein SR. A ladder of citizen participation. J Amer Plan Assoc. 1969;35(4):216-24.

21. Sanders AR, van Weeghel I, Vogelaar M, Verheul W, Pieters RH, de Wit $\mathrm{NJ}$, Bensing JM. Effects of improved patient participation in primary care on health-related outcomes: a systematic review. Fam Pract. 2013;30(4):365-78.

22. Gaghana VF, Siagian IET, Palandeng HMF, Monintja T. Tingkat Kepuasan Pasien Universal Coverage Terhadap Pelayanan Kesehatan di Puskesmas Tuminting Manado. Jurnal kedokteran Komunitas dan Tropik. 2014;2(1):21-6.

23. Putri NE. Efektivitas Penerapan Jaminan Kesehatan Nasional melalui BPJS dalam Pelayanan Kesehatan Masyarakat Miskin di Kota Padang. Tingkap. 2014;10(2):175-89.

24. Smith JA, Larkin MH, Flowers P. Interpretative phenomenological analysis: theory, method and research. Los Angeles: SAGE, 2009; 2009.

25. Kuncaraningrat Raden Mas. Javanese culture: Singapore; New York: Oxford University Press, 1985; 1985.

26. Smith JA, Osborn M. Interpretative phenomenological analysis. In: Smith JA, editor. Qualitative psychology: a practical guide to research methods. Thousand Oaks: Sage Publications, Inc; 2003. p. 51-80.

27. SEARO-WHO. Universal Health Coverage and Health Care Financing Indonesia. 2014. http://www.searo.who.int/indonesia/topics/hs-uhc/en/.

28. Hull TH. Reducing maternal and neonatal mortality in Indonesia: saving lives, saving the future. Andover: Taylor \& Francis; 2015.

29. Strengthening Australia Indonesia Partnership for Health System. Health Financing and Universal Health Coverage Compilation of Policy Notes. Jakarta; 2015.

30. Health Indonesian Ministry of Nusantara Sehat-Membangun Kesehatan Indonesia dari Perbatasan. 2016. http://nusantarasehat.kemkes.go.id/. Accessed 23 Dec 2016.

31. Indonesia The President of Republic, The Indonesian Government Regulation of Public Financial Management/PP Pengelolaan Keuangan Badan Layanan Umum. 2005. http://www.fti.itb.ac.id/wp-content/ uploads/2015/06/501-650-PP_No._23_Tahun_2005_tentang_PKBLU.pdf.

32. Cohen IJ. Structuration theory: Anthony Giddens and the constitution of social life: Houndmills, Basingstoke, Hampshire: Macmillan, 1989; 1989.
33. Rechel B, Ahmedov M, Akkazieva B, Katsaga A, Khodjamurodov G, McKee M. Lessons from two decades of health reform in Central Asia. Health Policy Plan. 2012;27(4):281-7.

34. Zhou XD, Li L, Hesketh T. Health system reform in rural China: voices of healthworkers and service-users. Soc Sci Med. 2014;117:134-41.

35. Starfield B. Primary care: an increasingly important contributor to effectiveness, equity, and efficiency of health services. SESPAS report 2012 Gac Sanit. 2012;26:20-6.

36. Hanratty $B$, Zhang T, Whitehead M. How close have universal health systems come to achieving equity in use of curative services? A systematic review. Int J Health Serv Plan Admin Eval. 2007;37(1):89-109.

37. Green LA, Fryer GE Jr, Yawn BP, Lanier D, Dovey SM. The ecology of medical care revisited. (Occasional Notes)(Statistical Data Included). N Engl J Med. 2001;2001(26):2021.

38. Darin Jaturapatporn, Saipin Hathirat. Specialists' perception of referrals from general doctors and family physicians working as primary care doctors in Thailand. Qual Prim Care. 2006;14(1):41-8.

39. Põlluste K, Kalda R, Lember M. Primary health care system in transition: the patient's experience. Int J Qual Health Care J Int Soc Qual Health Care Isqua. 2000;12(6):503-9.

40. Indonesia The President of Republic, Parliament The Indonesian, Indonesian Law of Medical Education, 1. 2013. http://sipuu.setkab.go.id/PUUdoc/173839/UU0202013.pdf.

41. Agustin Yusti Nurul. Ahli dan Saksi. Dokter Layanan Primer Rugikan Profesi Dokter Umum, A concern that primary care doctor program would disadvantage the general practitioners. Jakarta: Indonesian Constitutional Court; 2015. http://www.mahkamahkonstitusi.go.id/index. php?page=web.Berita\&id=10512\#.VkFU_rcrLcs.Accessed 28 Nov 2015.

42. Cynthia Haq, William Ventres, Vincent Hunt, Dennis Mull, Robert Thompson, Marc Rivo, et al. Where there is no family doctor: the development of family practice around the world. Acad Med. 1995;70(5):370-80.

43. Daeng $M$, Faqih MH, Mahesa PMH, Vidiawati D, Trisna CM-FM, Dyah A Waluyo, Herqutanto, Ekayanti F, Hendarto J,.Andi Alfian Zainuddin, Ika Hariyani. Panduan Praktik Klinis Bagi Dokter Di Fasilitas Pelayanan Kesehatan Primer. 1, editor. Jakarta: The Indonesian Ministry of Health; 2013.

44. Syah NA, Roberts C, Jones A, Trevena L, Kumar K. Perceptions of Indonesian general practitioners in maintaining standards of medical practice at a time of health reform. Fam Pract. 2015;32(5):584-90.

45. Starfield B. Primary care: an increasingly important contributor to effectiveness, equity, and efficiency of health services. SESPAS report 2012 Gac Sanit. 2012;26(Supplement 1(0)):20-6.

\section{Submit your next manuscript to BioMed Central and we will help you at every step:}

- We accept pre-submission inquiries

- Our selector tool helps you to find the most relevant journal

- We provide round the clock customer support

- Convenient online submission

- Thorough peer review

- Inclusion in PubMed and all major indexing services

- Maximum visibility for your research

Submit your manuscript at www.biomedcentral.com/submit
BioMed Central 